\title{
PELATIHAN MENULIS KALIGRAFI ARAB BAGI SISWA SD NO. 76/IX DESA MENDALO DARAT KEC. JALUKO KAB. MUARO JAMBI
}

\author{
Mohamad Muspawi \\ Dosen Program Studi Administrasi Pendidikan Fakultas FKIP Universitas Jambi \\ e-mail: muspawi01@gmail.com
}

\begin{abstract}
ABSTRAK
Kegiatan ini dilatar belakangi dari kunjungan awal tim pengabdian ke SD SD No. 76/IX Desa Mendalo Darat Kec. Jaluko Kab. Muaro jambi, yang mana ditemukan masih begitu banyak siswa yang belum mampu menulis kaligrafi Arab dengan baik dan benar, apalagi kalau sudah disebut dengan istilah seni kaligrafi, boleh dikatakan belum ada siswa pada SD tersebut yang mampu melakukannya dengan benar. Tujuan kegiatan pengabdian kepada masyarakat ini untuk memberikan bantuan keilmuan kepada para siswa tentang mengenal dan menulis kaligrafi Arab secara mendasar. Metode yang digunakan dalam pelatihan ini adalah metode demonstrasi, metode latihan, metode ceramah, metode penugasan, dan metode praktek. Hasil kegiatan pengabdian kepada masyarakat ini adalah: 1). Para peserta menunjukkan perhatian yang tinggi terhadap materi pengabdian yang disampaikan. 2). Para peserta menunjukkan reaksi yang positif terhadap cara mempraktekkan menulis kaligrafi Arab, mereka saling berpacu untuk menulis dengan baik dan benar. 3). Para peserta aktif bertanya dan mengungkapkan masalah-masalah yang dialaminya selama ini, dan mereka bersemangat untuk dapat menguasai menulis kaligrafi Arab dengan baik. 4). Para peserta terlihat bersemangat minta dibimbing secara pribadi ketika tim membuka layanan tersebut, sehingga tim juga merasa senang untuk segera dapat membimbing secara lebih dekat. 5). Para peserta terlihat kompak dan menjalin kerja sama yang cukup baik dalam latihan mempraktekkan menulis kaligrafi Arab. Mereka tampak saling bantu membantu dalam mengerjakan yang diberikan oleh tim pengabdian. Kesimpulan dari kegiatan pengabdian ini ialah: 1). Terjadi peningkatan pengetahuan dan keterampilan siswa tentang menulis kaligrafi Arab. Yang mana lebih dari $80 \%$ para peserta mampu mencontohkan menulis kaligrafi Arab seperti yang diajarkan oleh Tim Pengabdian 2). Meningkatnya semangat para siswa, yang mana mereka tampak lebih antusias dalam mempelajari kaligrafi Arab.
\end{abstract}

\section{Kata Kunci: Pelatihan , Kaligrafi, Siswa}

\section{PENDAHULUAN}

Salah satu sisi menariknya bahasa Arab adalah adanya seni kaligrafi Arab, yakni seni menulis indah dengan menggunakan huruf-huruf Arab. Keindahannya mampu mengundang daya tarik orang-orang yang melihatnya, terutama bagi mereka yang memang mencintai seni kaligrafi Arab. Keindahannya memiliki makna lebih, bagi mereka yang mampu memaknai kaligrafi Arab tidak hanya sekedar tulisan, tetapi ada nilai dan pesan keagamaan yang terkandung dari tulisan-tulisan yang tertata indah tersebut.

Bagi seorang muslim, kaligrafi Arab tidak hanya sebatas seni, tidak hanya sebatas hasil karya goresan tangan dengan penuh keindahan. Tetapi kaligrafi Arab bagi seorang muslim memiliki makna tersendiri, yakni: 1. Sebagai media untuk mengingat ayat-ayat Al-Qur'an, 
hadits, maqolah, atau mahfudzat. 2. Sebagai media untuk mendapatkan keberkahan dari khususnya ayat-ayat Al-Qur'an. 3. Sebagai hiasan rumah atau tempat tinggal yang mampu menambah nilai estetika tinggi. 4. Bagi penulisnya, sebagai salah satu sumber rezki, yang ketika dikerjakan secara profesional mampu menjadi penghasilan yang cukup menjanjikan.

Kata kaligrafi dalam bahasa Inggris disebut calligraphy (Echols, 1997:95), dalam bahasa Arab tulisan indah berarti khath (Alkalali, 1998: 102). Ungkapan kaligrafi diambil dari kata Latin kalios yang berarti indah, dan graph yang berarti tulisan atau aksara. Sementara di dalam kamus besar bahasa Indonesia (2002:494) kata kaligrafi diartikan dengan seni menulis indah dengan pena.

Kaligrafi menurut Sirojuddin (2000:3) adalah suatu ilmu yang memperkenalkan bentukbentuk huruf tunggal, letak-letaknya dan cara-cara penerapannya menjadi sebuah tulisan yang tersusun. Atau apa-apa yang ditulis di atas garis-garis sebagaimana menulisnya dan membentuknya mana yang tidak perlu ditulis, mengubah ejaan yang perlu diubah dan menentukan cara bagaimana untuk mengubahnya. Situmorang (1993:67) memberikan pengertian kaligrafi sebagai suatu corak atau bentuk seni menulis indah dan merupakan suatu bentuk keterampilan tangan serta dipadukan dengan rasa seni yang terkandung dalam hati setiap penciptanya.

Sedangkan kaligrafi Arab dapat dipahami dengan suatu seni menulis dengan menggunakan huruf-huruf Arab, kaligrafi Arab sering disebut dengan kaligrafi Islam, walaupun sebenarnya dalam tataran sebagai sebuah ilmu kaligrafi lebih bersifat terbuka, artinya ia bebas dilakukan oleh siapa saja tanpa memandang agama dan suku.

Kaligrafi pada umumnya memiliki beberapa fungsi antara lain: a. Kaligrafi merupakan salah satu sarana komunikasi dan pendekatan antar manusia, karena besarnya hubungan tulismenulis antar mereka dalam segala lapangan kehidupan. Kaligrafi dijadikan sebagai alat untuk menyampaikan pesan, dari seseorang ke orang lain dari komunikan ke receiver (penerima). Melalui tulisan, orang bisa menuangkan ide-ide dan buah pikirannya. Dengan tulisan, kita dapat mengetahui karakter seseorang, misalnya: pemarah, penyabar, ulet, atau orang yang tekun. b. Kaligrafi adalah salah satu media ekspresi. Hal itu dibuktikan oleh beberapa pelukis papan atas Indonesia seperti: Ahmad Sadali, A. D. Pirous, Amri Yahya, Amang Rahman, HD. Sirojuddin AR, Abay D. Sabarna, Saiful Adnan, Abas Alibasyah, Fadjar Sidik, dan yang lainnya, termasuk maestro seni lukis Indonesia Affandi pernah juga membuat kaligrafi Islam. Walau itu adalah lafadz "Allah" yang ditempatkan di sisi atas bidang kanvasnya digabungkan dengan lukisan potret diri Affandi yang khas. c. Bagi kaligrafer sendiri, membuat kaligrafi dapat membuat mereka memperoleh manfaat batiniah dan lahiriah ketika menguasai keterampilan menulis halus Arab ini. Selain menyajikan keindahan tulisan dan kedalaman makna dari pesan teks, kaligrafi juga bisa dijadikan media komunikasi dengan Sang Khalik. Lewat tulisan halus ini, seorang muslim dapat semakin mendekatkan diri pada Tuhan. d. Kaligrafi dapat membuat diri kita tenang. Beberapa kaligrafer mengakui merasa tenang saat sedang menulis kaligrafi. Dalam sehari, bahkan ada kaligrafi yang menghabiskan waktu lima jam untuk mengutak-atik huruf-huruf indah tersebut. e. Sebagian apresiator merasakan kenikmatan memandang dan menelaahnya karena adanya unsur-unsur estetis pada huruf-huruf dan harakatnya. Kaligrafi menarik ekspresi, dicintai kalangan-kalangan tertentu dan umum. Untuk itulah, sebuah karya selalu mendampingi 
mereka di rumah dan tempat-tempat mereka bekerja, bahkan kemanapun mereka pergi. f. Kaligrafi merupakan sarana mencari rezeki, mengingat bahwa ia adalah seni yang berbobot nilai tinggi dengan kedudukan puncak yang pernah dicapai para ahlinya (seperti jabatan Perdana Menteri). Bagi seorang fakir, kaligrafi adalah uang, bagi seorang hartawan, ia adalah keindahan. g. Kaligrafi merupakan sarana mencari rezeki, mengingat bahwa ia adalah seni yang berbobot nilai tinggi dengan kedudukan puncak yang pernah dicapai para ahlinya (seperti jabatan Perdana Menteri). Bagi seorang fakir, kaligrafi adalah uang, bagi seorang hartawan, kaligrafi adalah keindahan.

Menulis kaligrafi Arab memiliki cara, metode, atau kaedah tersendiri (Makin, 1995:2). makanya ada orang yang mengatakan sulit untuk bisa menulis kaligrafi Arab, sehingga tidak banyak jumlah orang yang mampu menguasai penulisan kaligrafi Arab dengan baik dan benar. Padahal menulis kaligrafi Arab cukup mudah asalkan diikuti dengan penuh kesungguhan dan mengikuti kaedah penulisan yang benar. Ketelitian dan kesabaran juga merupakan hal yang dimiliki oleh mereka yang ingin mampu menguasai seni menulis kaligrafi Arab.

Menulis kaligrafi sebenarnya pekerjaan yang mudah, asalkan mampu mengikuti beberapa hal berikut: 1. Semangat yang tinggi, yakni semangat untuk terus belajar hingga bisa menulis kaligrafi dengan baik dan benar. 2. Keyakinan yang kuat, yakni yakin bahwa kita sanggup juga menjadi orang yang mampu menulis kaligrafi dengan baik dan benar. 3. Sabar, yakni sabar untuk mengikuti proses latihan dengan berbagai halangan dan rintangan hingga sukses. 4. Mau berkorban, yakni mau mengorbankan waktu, tenaga, dan biaya demi menjadi kaligrafi yang handal.

Kenyataan di lapangan, berdasarkan kunjungan tim pengabdian ke SD SD No. 76/IX Desa Mendalo Darat Kec. Jaluko Kab. Muaro jambi masih begitu banyak siswa yang belum mampu menulis kaligrafi Arab dengan baik dan benar, apalagi kalau sudah disebut dengan istilah seni kaligrafi, boleh dikatakan belum ada siswa pada SD tersebut yang mampu melakukannya dengan benar.

Bertolak dari pemikiran di atas, tim pengabdian merasa terpanggil untuk melaksanakan kegiatan pelatihan kepada anak-anak usia sekolah dasar, dalam hal ini siswa SD No. 76/IX Desa Mendalo Darat Kec. Jaluko Kab. Muaro Jambi, tentang menulis kaligrafi Arab yang nantinya semoga dapat bermanfaat di dalam kehidupan sehari-hari.

Berdasarkan uraian di atas, maka tim pengabdian melakukan kegiatan pelatihan yang ditujukan kepada para siswa SD No. 76/IX Desa Mendalo Darat Kec. Jaluko Kab. Muaro Jambi, dengan materi kegiatan meliputi:

1. Memberikan penjelasan mengenai pengertian kaligrafi Arab.

2. Memberikan penjelasan mengenai fungsi kaligrafi Arab.

3. Memberikan penjelasan mengenai jenis kaligrafi Arab.

4. Mendemonstrasikan langkah-langkah menulis kaligrafi Arab yang baik dan benar.

5. Mendemonstrasikan contoh-contoh kaligrafi Arab.

Tujuan pengabdian masyarakat ini untuk memberikan bantuan keilmuan kepada para siswa SD No. 76/IX Desa Mendalo Darat Kec. Jaluko Kab. Muaro Jambi tentang mengenal dan menulis kaligrafi Arab secara mendasar. Sedangkan manfa'atnya ialah diharapkan memberikan efek positif yakni berupa meningkatnya kemampuan siswa-siswi dalam menulis 
kaligrafi Arab, serta menunjukkan semangat yang baik untuk terus memperdalam menulis kaligrafi Arab.

\section{METODE PELAKSANAAN}

\section{A. Kerangka Pemecahan Masalah.}

Adapun kerangka pemecahan masalah dalam pengabdian ini adalah sebagai berikut: 1. Tim melakukan peninjauan kemampuan siswa dalam menulis kaligrafi Arab. 2. Tim melakukan pelatihan mengenai menulis kaligrafi Arab, yakni dengan memberikan penjelasanpenjelasan, menampilkan contoh-contoh, dan mendemonstrasikan cara menulis kaligrafi Arab yang baik dan benar. 3. Tim memberikan kesempatan kepada siswa memperdalam pengetahuan mengenai menulis kaligrafi Arab dengan banyak latihan demi latihan. 4. Tim melakukan evaluasi untuk mengukur pencapaian kemampuan oleh para peserta pelatihan. 5 . Tim melakukan kunjungan beberapa kali untuk melakukan pendalaman penguasaan menulis kaligrafi Arab bagi para peserta. 6. Tim melakukan evaluasi lanjutan untuk mengetahui peningkatan pengetahuan dan penguasaan menulis kaligrafi Arab oleh para peserta.

\section{B. Realisasi Pemecahan Masalah.}

Kegiatan yang dilakukan dalam mencapai tujuan pengabdian kepada masyarakat ini adalah sebagai berikut:

1. Persiapan.

a. Mengurus surat izin dan surat tugas untuk melaksanakan kegiatan pengabdian kepada masyarakat.

b. Menghubungi kepala SD No. 76/IX Desa Mendalo Darat Kec. Jaluko Kab. Muaro Jambi untuk menetapkan jumlah peserta dan jadwal pelaksanaan pengabdian kepada masyarakat.

\section{Pelaksanaan.}

Kegiatan pengabdian kepada masyarakat ini dilaksanakan pada tanggal 17-9-2016 dengan agenda pelatihan menulis kaligrafi Arab tahap pertama, 21-9-2016 lanjutan pelatihan menulis kaligrafi Arab tahap kedua, dan tanggal 19-10-2016 tahap validasi dan finalisasi di SD No. 76/IX Desa Mendalo Darat Kec. Jaluko Kab. Muaro Jambi.

\section{Khalayak Sasaran.}

Sebagai peserta dari kegiatan pengabdian kepada masyarakat ini adalah para siswa pelatihan menulis kaligrafi Arab tahap pertama, yang terdiri atas 30 orang siswa-siswi, semuanya berasal dari kelas $\mathrm{V}$.

\section{Metode yang digunakan.}

Metode yang digunakan dalam melaksanakan kegiatan pengabdian ini adalah metode ceramah, demonstrasi, dan metode penugasan. Tim pengabdian mengawali kegiatan dengan menjelaskan mengenai pemahaman tentang kaligrafi, meliputi pengertian kaligrafi Arab, tujuan mempelajari kaligrafi Arab, kelebihan mempelajari kaligrafi Arab, dan langkahlangkah mempelajari kaligrafi Arab. Selanjutnya tim melakukan demonstrasi menuliskan teks-teks Arab sesuai dengan kaedah kaligrafi pada papan tulis yang tersedia, lalu memerintahkan para siswa-siswi untuk ikut menulis dengan mencontoh tulisan yang dicontohkan oleh tim pengabdian. 


\section{HASIL YANG DICAPAI}

Berdasarkan pengamatan selama kegiatan pengabdian kepada masyarakat berlangsung, diperoleh beberapa hasil yang positif, diantaranya adalah:

1. Para peserta menunjukkan perhatian yang tinggi terhadap materi pengabdian yang disampaikan oleh tim pengabdian. Yang mana peserta memfokuskan perhatian mereka terhadap kegiatan ini, dan peserta mengesampingkan kegiatan lainnya dalam rangka serius mengikuti kegiatan pengabdian ini.

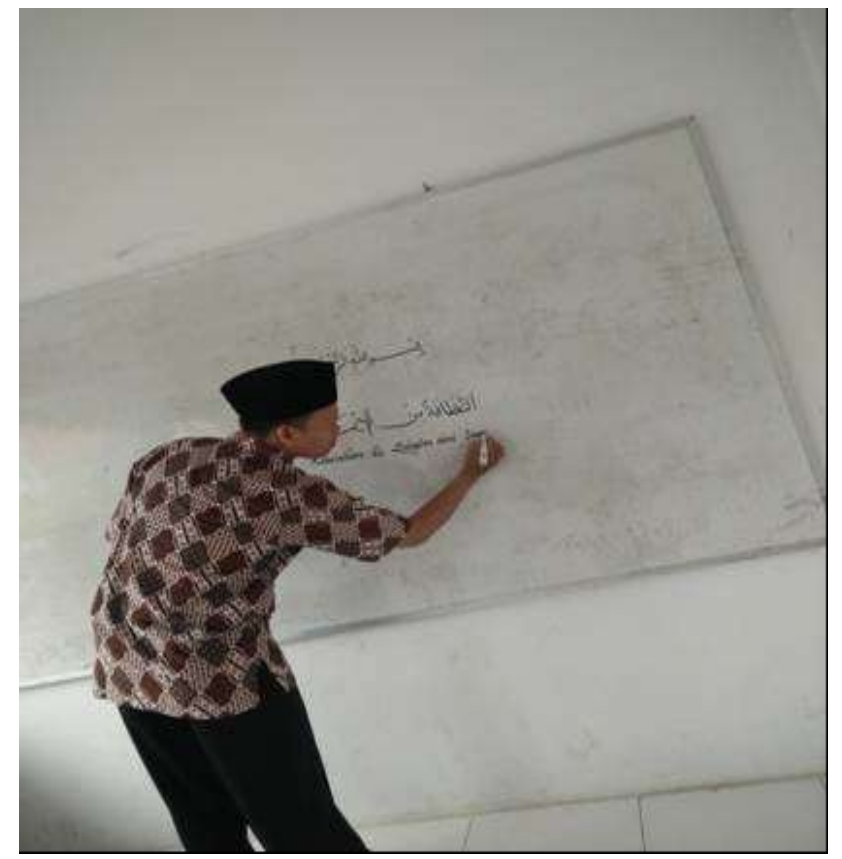

Gambar 1: Tim pengabdian mempraktekkan contoh menulis kaligrafi Arab di papan tulis. (Sumber; Dokumentasi tim pengabdian)

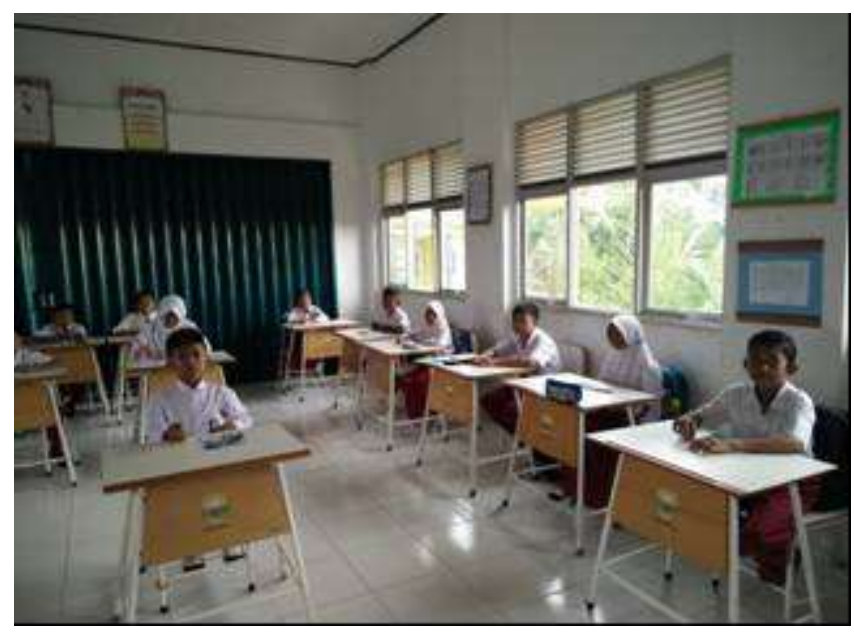

Gambar 2: Para siswa terlihat antusias mengikuti kegiatan pelatihan, dan memperhatikan secara seksama ketika tim pengabdian mempraktekkan contoh menulis kaligrafi Arab di papan tulis. (Sumber: Dokumentasi tim pengabdian). 
2. Para peserta menunjukkan reaksi yang positif terhadap cara mempraktekkan menulis kaligrafi Arab, mereka saling berpacu untuk menulis dengan baik dan benar, dan ketika tim pengabdian menyuruh untuk maju secara bergantian menulis di papan tulis, telihat para peserta pengabdian antusias ingin segera mendapatkan giliran.

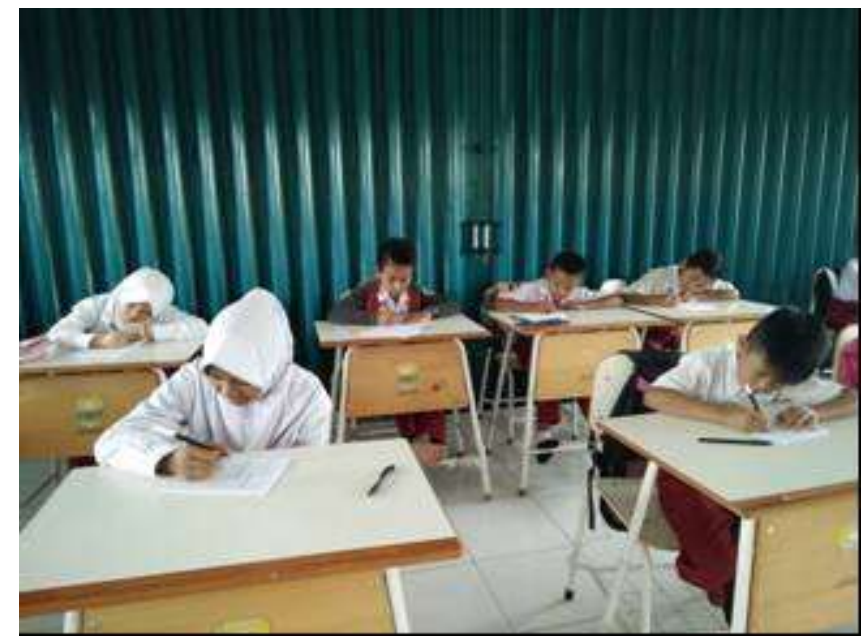

Gambar 3: Para siswa terlihat antusias mempraktekkan menulis kaligrafi arab pada buku tulis yang sudah disediakan oleh tim pengabdian. (Sumber: Dokumentasi tim pengabdian)

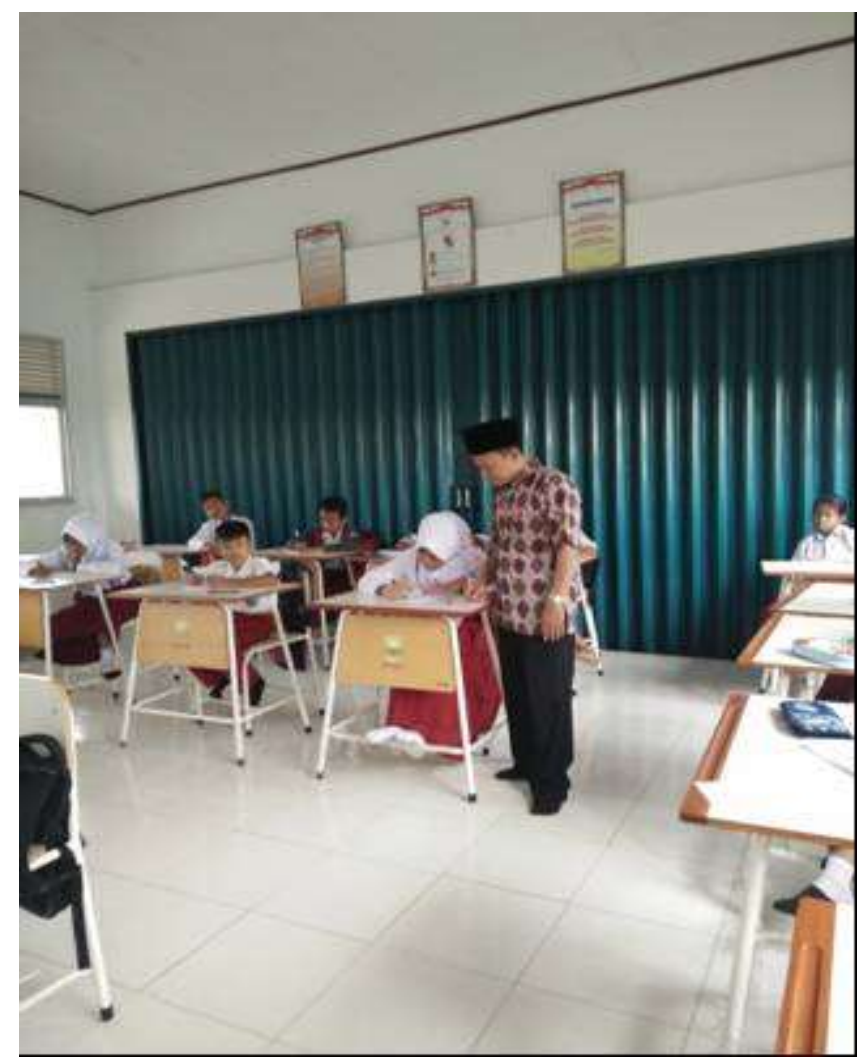

Gambar4:Tim pengabdian memberikan bimbingan kepada para siswa. (Sumber: Dokumentasi tim pengabdian) 


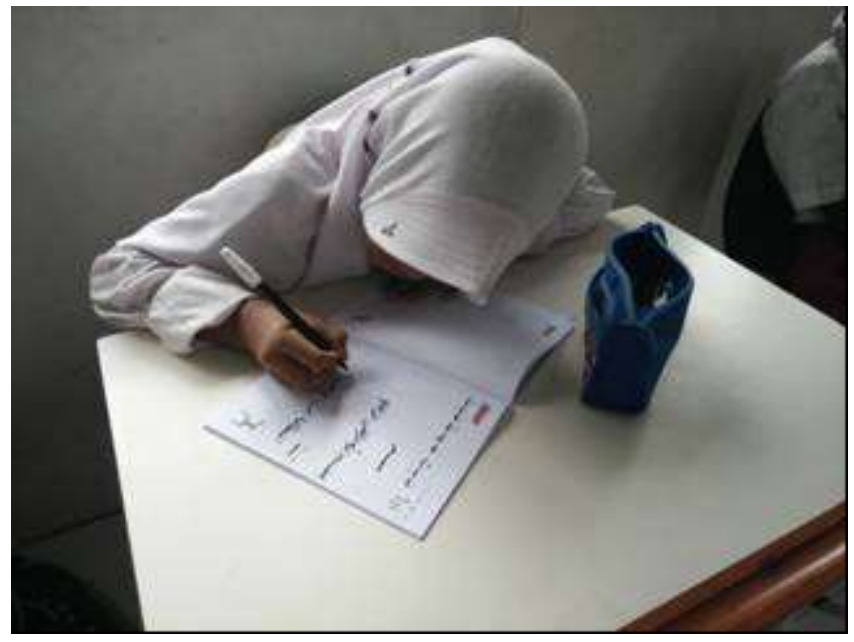

Gambar 5: Salah seorang siswa terlihat sangat serius mempraktekkan penulisan kaligrafi Arab. (Sumber: Dokumentasi tim pengabdian)

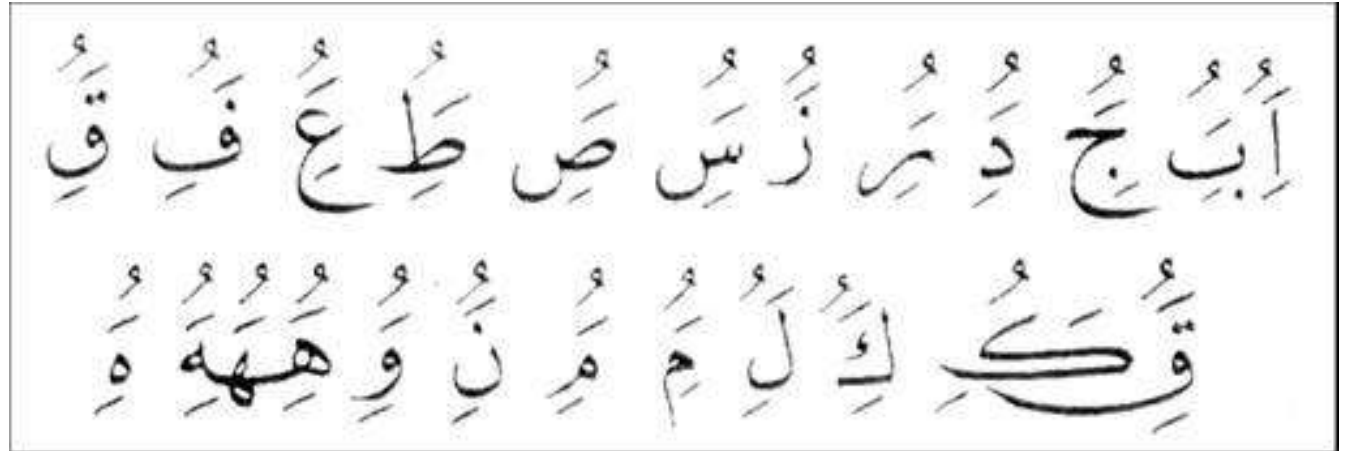

Gambar 6: Salah satu contoh penulisan huruf Hijaiyah dalam bentuk Khat Naskhi. (Sumber: Munir, 1998:3)

3. Para peserta aktif bertanya dan mengungkapkan masalah-masalah yang dialaminya selama ini, dan mereka bersemangat untuk dapat menguasai menulis kaligrafi Arab dengan baik.

4. Para peserta terlihat bersemangat minta dibimbing secara pribadi ketika tim membuka layanan tersebut, sehingga tim juga merasa senang untuk segera dapat membimbing secara lebih dekat.

5. Para peserta terlihat kompak dan menjalin kerja sama yang cukup baik dalam latihan mempraktekkan menulis kaligrafi Arab. Mereka tampak saling bantu membantu dalam mengerjakan yang diberikan oleh tim pengabdian.

\section{Pembahasan.}

Berdasarkan kegiatan pelatihan ini, telah terjadi peningkatan pengetahuan dan keterampilan menulis kaligrafi Arab bagi para peserta. Yang mana dapat disampaikan bahwa lebih dari $80 \%$ para peserta mampu mencontohkan menulis kaligrafi Arab seperti yang diajarkan oleh Tim Pengabdian, paling tidak peningkatan tersebut terlihat jika dibandingkan dengan kemampuan mereka sebelum mengikuti kegiatan pengabdian ini. 
Ditinjau dari segi materi pengabdian yang disampaikan, banyak pengalaman atau pengetahuan dan keterampilan baru yang diperoleh oleh para siswa SD No. 76/IX Desa Mendalo Darat Kec. Jaluko Kab. Muaro Jambi. Yakni mengenai menulis kaligrafi Arab yang diakui oleh sebagian besar siswa merupakan keterampilan yang baru mereka pelajari. Sebab, ketika tim pengabdian dalam kunjungan awal meninjau kemampuan SD No. 76/IX Desa Mendalo Darat Kec. Jaluko Kab. Muaro Jambi mengenai keterampilan menulis kaligrafi Arab, sebagian besar siswa memang belum mengenal dengan baik mengenai menulis kaligrafi Arab.

Kemudian, bagi tim pengabdian juga memperoleh beberapa input yang bermanfa'at tentang berbagai masalah yang dialami para siswa SD No. 76/IX Desa Mendalo Darat Kec. Jaluko Kab. Muaro Jambi, baik mengenai kendala-kendala yang mereka rasakan dalam mempelajari kaligrafi Arab, maupun mengenai rasa senangnya mereka mempelajari kaligrafi Arab. Semua pengalaman tersebut dapat tim pengabdian gunakan sebagai bahan pertimbangan untuk melaksanakan pengabdian kepada masyarakat di masa-masa yang akan datang. Secara umum kegiatan pengabdian kepada masyarakat yang dilaksanakan oleh tim pengabdian masyarakat ini tidaklah menemukan kendala yang cukup serius, dalam artian bahwa pelaksanaan kegiatan ini cukup lancar. Hanya saja karena keterbatasan dana untuk pelaksanaan pengabdian ini, maka hal tersebut menyebabkan keterbatasan bentuk, jenis, dan waktu pelaksanaan kegiatan.

\section{KESIMPULAN DAN SARAN}

\section{A. Kesimpulan.}

Berdasarkan uraian yanag telah dikemukakan pada bagian sebelumnya, diperoleh kesimpulan bahwa kegiatan pengabdian kepada masyarakat ini dapat:

1. Terjadi peningkatan pengetahuan dan keterampilan siswa tentang menulis kaligrafi Arab. Yang mana lebih dari $80 \%$ para peserta mampu mencontohkan menulis kaligrafi Arab seperti yang diajarkan oleh Tim Pengabdian.

2. Meningkatnya semangat para siswa, yang mana mereka tampak lebih antusias dalam mempelajari kaligrafi Arab.

\section{B. Saran.}

Berdasarkan kepada hasil yang diperoleh maka dapat disarankan beberapa hal sebagai berikut:

1. Berdasarkan permintaan dari peserta, hendaknya kegiatan-kegiatan seperti ini dapat ditingkatkan frekwensi pelaksanaannya.

2. Biaya untuk pelaksanaan kegiatan ini hendaknya lebih ditingkatkan, sehingga dapat melaksanakan kegiatan lebih variatif dan waktu lebih lama.

\section{UCAPAN TERIMAKASIH}

Ucapan terimakasih penulis sampaikan kepada Kementerian Riset, Teknologi dan Pendidikan Tinggi yang telah mendanai kegiatan pengabdian ini melalui sumber dana DIPA/042.01.2.400950/2016 tanggal 07 Desember 2015. dan Surat Perjanjian Pelaksanaan Pengabdian Kepada Masyarakat Program FKIP Nomor: 496/UN21.7/PM/2016, tanggal 1 Juli 2016. 


\section{DAFTAR PUSTAKA}

Afifi, Fauzi salim, Cara Mengajar Kaligrafi Pedoman Guru, diterjemahkan oleh D. Sirojuddin, Jakarta: Darul Ulum Press, 2002.

Ahmad, Abd. Aizi, Ragam Karakter Kaligrafi, Jakarta: Bumi Aksara, 2001.

D. Sirojuddin AR, Keterampilan Menulis Kaligrafi Bagi santri Pondok Pesantren, Jakarta: Departemen Agama RI, 2001.

Dewan Redaksi Ensiklopedi Islam, "Kaligrafi”, Ensiklopedi Islam, Jakarta: Ichtiar Baru Van Hoeve, 1997.

El-Iskandar, Boby Es-Syawal, Ragam Hiasan Mushaf Nusantara: Panduan Teknik Pengolahan Hiasan Mushaf, Jakarta: Balemedia, 2003.

Hasyim Muhammad Al-Khaththath, Qowa'idul Khaththil ‘Arabi, Baghdad, 1960.

Husain, Abdul Karim, Khat Seni Kaligrafi, Surabaya: Menara Kudus, 1971.

Munir Misbahul, Mengenal Kaidah Kaligrafi Al-Qur'an, Semarang: Binawan, 2004.

Munir Misbahul, Panduan Kaligrafi Arab, Surabaya: Apollo, 2000. 